\title{
Effect of low dosage of coagulant on the ultrafiltration membrane performance in feedwater treatment
}

\author{
Baiwen $M a^{a, b}$, Wenzheng $\mathrm{Yu}^{a}$, Huijuan Liu ${ }^{a}$, Jiuhui $\mathrm{Qu}{ }^{a, *}$ \\ a State Key Laboratory of Environmental Aquatic Chemistry, Research Center for Eco-Environmental Sciences, \\ Chinese Academy of Sciences, Beijing 100085, China \\ ${ }^{\mathrm{b}}$ University of Chinese Academy of Sciences, Beijing 100049, China
}

\section{A R T I C L E I N F O}

Article history:

Received 29 July 2013

Received in revised form

27 October 2013

Accepted 28 October 2013

Available online 7 November 2013

Keywords:

Aluminum chloride

Low dosage

Critical dose

Ultrafiltration

Flux decline

\begin{abstract}
A B S T R A C T
One of the critical issues for the widely application of ultrafiltration (UF) in water treatment is membrane fouling owning to the dissolved organic matter. The aim of the present study is to explore the effect of various particle sizes caused by low dosages of coagulant with dissolved organic matter on the UF membrane performance. Aluminum chloride was added to the synthetic water with the hydrophobic humic acid (HA), the hydrophilic bovine serum albumin (BSA) - a protein- and their 1:1 (mass ratio) mixture. The results showed that there was a critical dose of $\mathrm{Al}$ that could cause dramatic flux reduction by blocking the membrane pores after coagulating with HA/BSA. For HA or BSA, the critical dose of Al was relatively lower at $\mathrm{pH} 6.0$ than that at $\mathrm{pH}$ 8.0. After coagulation, the flux decline caused by HA was slightly varied as a function of $\mathrm{pH}$ while that caused by BSA was greatly affected by pH. The flux decline caused by the 1:1 (mass ratio) HA/BSA mixture after coagulation was similar to that caused by HA after coagulation because BSA could be encapsulated by HA. In addition, the peak value of the molecular weight (MW) distribution of HA coagulated with Al was changed more drastically compared to that of BSA after filtration.
\end{abstract}

(c) 2013 Elsevier Ltd. All rights reserved.

\section{Introduction}

Ultrafiltration (UF) membrane has been widely used in drinking water treatment due to its excellent properties, such as removing a variety of waterborne viruses and much of the dissolved organic matter, etc. (Kimura et al., 2004; Jermann et al., 2007; Porcelli and Judd, 2010). However, a major impediment in the application of UF membrane technology is membrane fouling. The UF membrane could be polluted by three different ways: pore constriction, pore blocking and cake layer (Jucker and Clark, 1994; Yuan and Zydney, 1999; Aoustin et al., 2001; Katsoufidou et al., 2007). The occurrence of different mechanisms of membrane fouling is related to particle size relative to membrane pore size (Huang et al., 2008) and other influence factors (Maximous et al., 2009; Katsoufidou et al., 2010; Masatoshi et al., 2011). The particle sizes which are close to the diameter of membrane pores can cause pore blocking, resulting in the most severe membrane fouling.

There are many different substances which co-exist in the complex natural water. Now more and more studies have

\footnotetext{
* Corresponding author. Tel.: +8610 62849160; fax: +86 1062923558.

E-mail addresses: jhqu@rcees.ac.cn, jhqu@mail.rcees.ac.cn (J. Qu).
} 
focused on two or more contaminants in the solution, and some different pollution mechanisms have really been found compared to only one single pollutant in feed water (Jermann et al., 2007; Katsoufidou et al., 2010; Zazouli et al., 2010). Humic acid (HA) and bovine serum albumin (BSA) are used as model contaminants for their widely application in many studies (Tang and Leckie, 2007; Mo et al., 2008; Listiarini et al., 2009; She et al., 2009; Huber et al., 2011; Wang and Tang, 2011).

Coagulation remains the most common process to remove turbidity and nature organic matter (NOM) in water treatment, and $\mathrm{Al} / \mathrm{Fe}$ salts are widely used as coagulants for pretreatment (Shon et al., 2004, 2005; Lee et al., 2009; Wang et al., 2009). Albased or Fe-based salts could form a series of cationic hydrolytic species and weakly charged or uncharged precipitates after reacting with water (Stumm and Morgan, 1996; O'Melia, 1998). Al-Malack and Anderson (1996) determined the optimal coagulation conditions for wastewater which was $200 \mathrm{mg} / \mathrm{L} \mathrm{FeCl}_{3}$ at $\mathrm{pH}$ 9.0, and the chemical oxygen demand (COD) removal efficiency by this optimal dose of $\mathrm{FeCl}_{3}$ was about 99.3\%. Aguiar et al. (1996) found that the optimal dose of coagulant was $2.1 \pm 0.2 \mathrm{mg}$ Fe per $\mathrm{mg}$ of total organic carbon (TOC). In recent years, some studies have focused on finding an optimal dose in order to dramatically reduce the membrane fouling in the downstream treatment of membrane filtration. Tran et al. (2006) found that a specified dose of Al which could remove dissolved organic carbon (DOC) effectively also reduced the polyvinylidene fluoride (PVDF) microfiltration (MF) membrane fouling. Lee et al. (2009) reported that there was an optimal PACl dosage with respect to fouling minimization, depending on the specific characteristics of wastewater. The optimal PACl dose was shifted to a higher level with increasing the ionic strength. They found that $0.0371 \mathrm{mM}$ PACl (calculated as $\mathrm{Al}$ ) was needed to achieve the highest UF membrane flux with a low ionic strength $(546 \mu \mathrm{S} /$ $\mathrm{cm}$ ) while approximately $0.5 \mathrm{mM} \mathrm{PACl}$ could achieve the maximal flux when the ionic strength was much higher $(2390 \mu \mathrm{S} / \mathrm{cm})$. According to the results presented by Shon et al. (2005), there was an optimal dose of $\mathrm{FeCl}_{3}$ which did not cause any flux decline during the whole operation of UF in $6 \mathrm{~h}$. Finally they showed that at least $50 \mathrm{mg} / \mathrm{L} \mathrm{FeCl}_{3}$ was found to be necessary to avoid any significant flux decline and to obtain a better DOC removal efficiency. Up to now, more and more studies are focused on finding an optimal dose of coagulant to reduce the membrane fouling in the downstream treatment. However, few have been paid attention to the phenomenon that whether the membrane will be fully blocked by a critical dose of coagulant or not. Herein the key issue that we concern about is to know the membrane flux decline induced by the various particle sizes formed by HA/BSA coagulated with low dosages of $\mathrm{Al}$.

This research focuses on the fouling mechanism of UF membrane at the low dosage coagulant. It aims at: (1) whether there is a critical dose of $\mathrm{Al}$ that can cause membrane flux reduce significantly or even fully block the membrane pores as a function of time, $\mathrm{pH}$, etc. after coagulating with the hydrophobic HA or the hydrophilic BSA; if there is, then, (2) whether the critical dose of Al would be different for HA or BSA; and (3) what the critical dose of $\mathrm{Al}$ would be if the feed water is mixed by HA and BSA.

\section{Materials and methods}

\subsection{Chemical regents and materials}

All chemicals were analytical reagent except for specific illustration and the deionized (DI) water was used for preparation of all stock solutions and membrane performance experiments. $\mathrm{pH}$ was adjusted by $0.1 \mathrm{M} \mathrm{HCl}$ or $0.1 \mathrm{M}$ $\mathrm{NaOH}$ by pre-determined. Humic acids, sodium salt (HA, Aldrich, USA) was dissolved by DI water while BSA (Electrophoresis Pure, Sinopharm Chemical Regent Co., Ltd, China) was dissolved by solutions of $0.15 \mathrm{M}$ ionic strength phosphate buffered salt (Sean et al., 1993). Stock solutions of HA and BSA at a total concentration of $10 \mathrm{~g} / \mathrm{L}$ were prepared. BSA working solutions were used within two days (Sean et al., 1993). Aluminum chloride $\left(\mathrm{AlCl}_{3} \cdot 6 \mathrm{H}_{2} \mathrm{O}\right.$, calculated as Al) was used as coagulant here and the stock concentration was $0.1 \mathrm{M}$. Working solutions were stored in the dark at $4{ }^{\circ} \mathrm{C}$ and all experiments were repeated for 2 or 3 times.

\subsection{UF experiments}

The UF membrane (PVDF) was used here with nominal molecular weight cutoff of $100 \mathrm{kDa}$. Each membrane was placed in DI water for at least $24 \mathrm{~h}$ to remove impurities and production residues. Immediately before the stirred cell test the DI water flux of the membrane was determined by filtering DI water through the membrane until reached a stable permeate flux. Normalized flux $J / J_{0}$ as a function of time was shown for the flux decline results from the stirred cell experiments, and $J_{0}$ was the initial membrane flux. Using UF stirred cell (Milipore, Amicon 8400) and keeping the pressure stable ( $0.1 \mathrm{MPa}$ ) by nitrogen gas, the fouling characteristics of the flat sheet UF membrane were studied by filtering dilute $\mathrm{HA}$ and BSA in the presence of different doses of $\mathrm{Al}$ in feed solution.

For the tests, the aluminum chloride stock solution was diluted in DI water $(300 \mathrm{ml})$, in the UF stirred cell, with $0.1 \mathrm{M}$ $\mathrm{NaHCO}_{3}$ to give test solution. During the test, the $\mathrm{pH}$ of final solution was maintained by prior addition of a predetermined amount of $0.1 \mathrm{M} \mathrm{NaOH}$ or $0.1 \mathrm{M} \mathrm{HCl}$. Afterward $10 \mathrm{ppm} \mathrm{HA}$, 1:1 $1_{\text {ratio }} 5$ ppm HA/BSA mixture or 10 ppm BSA were formed by adding the corresponding stock solution to the feed water. Rapid mixing (250 rpm) lasted for $1 \mathrm{~min}$ while slow mixing (100 rpm) lasted for $14 \mathrm{~min}$ to allow floc growth to occur and taking out the stirrer carefully finally.

\subsection{Analytical methods}

$\mathrm{pH}$ was measured by Orion $\mathrm{pH}$ Benchtop; Variation of UF membrane flux as a function of time was recorded by data logger; Molecular weight distribution was determined by Gel Permeation Chromatography (GPC, Agilent Technologies, USA; Detector: $\mathrm{UV}_{254}$; Column: TSK; Temperature: $25{ }^{\circ} \mathrm{C}$ ); Particle size was measured by Zeta Sizer (Malvern Instrument, Nano Series, Nano-ZS, Model: ZEN3600); Ultrafiltration membrane pore size was analyzed by IB-FT, GmbH (POROLUX 1000, Germany). 


\section{Results}

\subsection{Flux decline caused by the critical dose of $\mathrm{Al}$}

In order to investigate whether there was a critical dose of $\mathrm{Al}$ that would cause the membrane flux decline significantly as a function of time after coagulating with HA or BSA, different low doses of $\mathrm{Al}$ were added to the feed water at $\mathrm{pH} 7.0$ with $10 \mathrm{ppm}$ $\mathrm{HA}, 1: 1_{\text {ratio }} 5 \mathrm{ppm} \mathrm{HA} / \mathrm{BSA}$ mixture or $10 \mathrm{ppm}$ BSA, respectively. For $\mathrm{HA}, 1: 1_{\text {ratio }} 5 \mathrm{ppm} \mathrm{HA} / \mathrm{BSA}$ and $\mathrm{BSA}$, their $\mathrm{J} / \mathrm{J}_{0}$ values reduced firstly and then increased with increasing the dose of $\mathrm{Al}$ (Fig. 1). It clearly showed that there was indeed a critical dose of $\mathrm{Al}$ that could cause the flux reduce dramatically after coagulation, especially for BSA. Ye et al. (2005a,b; 2006) found that membrane flux decline was induced by pore constriction in a short time, and by cake layer over a long period of time. In fact, the critical dose of Al was a boundary point, which meant that the main flux decline was caused by adsorption when the dose of Al was lower than the critical dose, and that was caused by cake layer when the dose of Al was higher than the critical dose. Compared to the flux decline caused by HA after coagulation with $\mathrm{Al}$, the flux decline caused by BSA after coagulation was much more significant. Fig. 1 showed the minimal $J / J_{0}$ value caused by HA coagulated with Al was about 0.64 while that caused by BSA after coagulation was about 0.36 . The wide MW distribution of HA (Yuan and Zydney, 1999) inferred that it was difficult to reach a particle size which could cause serious flux decline compared to that of BSA, of which the MW distribution was relatively much narrow (electrophoresis pure).

Studies have demonstrated that protein could be encapsulated by humic substances (HS) because of the protein-HS electrostatic attraction (Knicker and Hatcher, 1997; Zang et al., 2000; Hsu and Hatcher, 2005, 2006; Tan et al., 2008; Tan et al.,
2009). Thus, the $J / J_{0}$ value caused by $1: 1_{\text {ratio }} 5 \mathrm{ppm} \mathrm{HA} / \mathrm{BSA}$ mixture was similar to that caused by HA after coagulation. However, things would be different when there was little HA in the mixture solution because more BSA molecules were free.

\subsection{Critical dose influenced by $\mathrm{pH}$}

To know exactly whether the $\mathrm{pH}$ of the feed water could inference the critical dose of $\mathrm{Al}$ or not, fouling experiments were performed with solutions at pH 6.0, 7.0 and 8.0 (Figs. 1 and 2). It was presented that the flux declines caused by HA or $1: 1_{\text {ratio }}$ $5 \mathrm{ppm}$ HA/BSA mixture were almost the same after coagulation. However, the membrane flux decline caused by BSA after coagulation was much more serious than those caused by HA or $1: 1_{\text {ratio }} 5 \mathrm{ppm} \mathrm{HA} / \mathrm{BSA}$ mixture after coagulation. The flux decline caused by BSA coagulated with $\mathrm{Al}$ at $\mathrm{pH} 6.0\left(\mathrm{~J} / \mathrm{J}_{0}=0.24\right)$ or $7.0\left(\mathrm{~J} / \mathrm{J}_{0}=0.46\right)$ was smaller than that at $\mathrm{pH} 8.0\left(\mathrm{~J} / \mathrm{J}_{0}=0.66\right)$. Palacio et al. (2003) have demonstrated that BSA always polluted the membrane by internal pollution, and Al species were not the same as a function of $\mathrm{pH}$ which would form various particle sizes (Wang et al., 2008). Therefore, the minimal $\mathrm{J} / \mathrm{J}_{0}$ value induced by BSA coagulated with $\mathrm{Al}$ was varied as a function of $\mathrm{pH}$ after coagulation (Figs. 1c and 2c,f). Furthermore, BSA could cause serious flux decline at its iso electric point (IEP, $\mathrm{pH}$ 4.7) because there was no electrostatic interaction between BSA and membrane while the membrane fouling was mitigated when the $\mathrm{pH}$ was far away from its IEP (Palacio et al., 2003).

Fig. 3 described the minimal $J / J_{0}$ value induced by the critical dose of Al after coagulating with $\mathrm{HA}$ or BSA as a function of $\mathrm{pH}$. It showed that the minimal membrane flux caused by BSA after coagulation was significantly affected as a function of $\mathrm{pH}$ while that caused by HA or 1:1 ratio $5 \mathrm{ppm} \mathrm{HA} /$ BSA mixture was changed little after coagulation. According
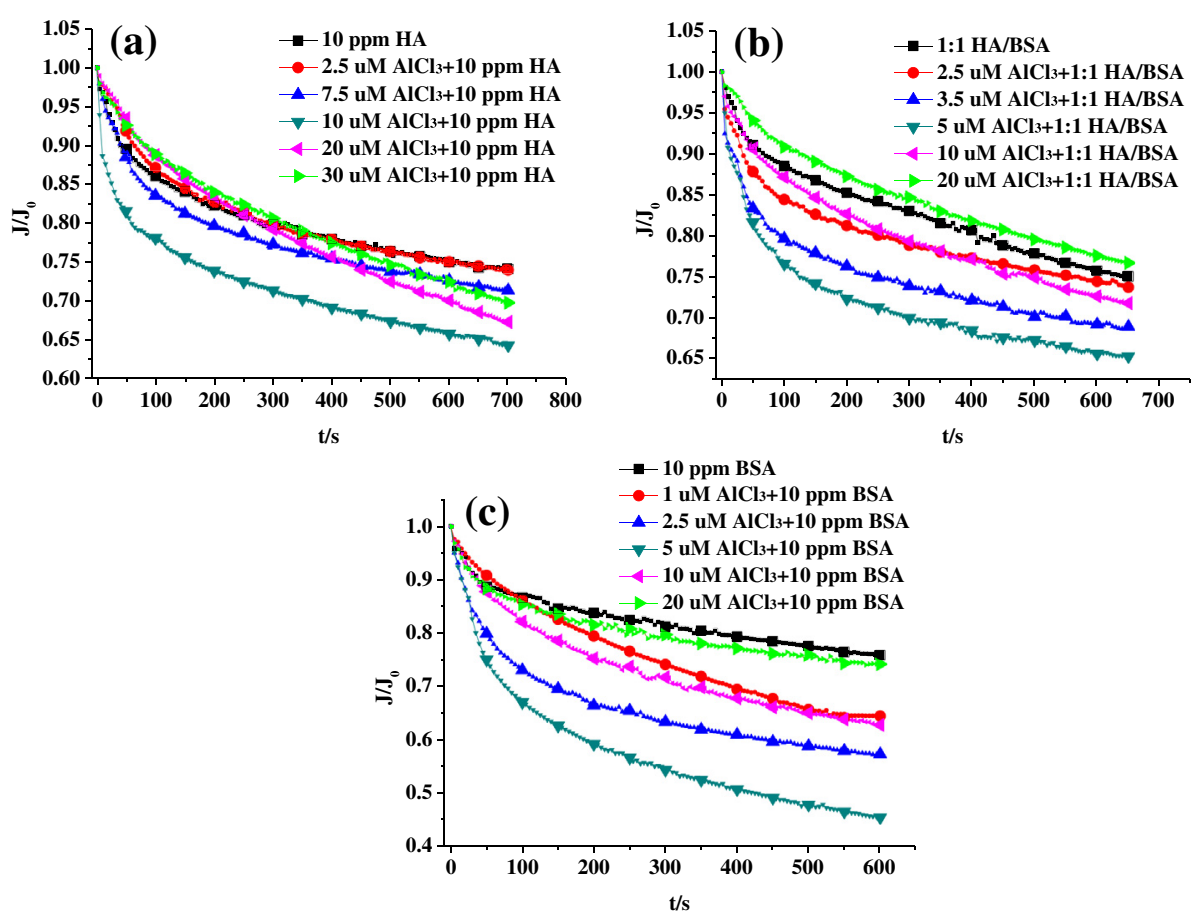

Fig. 1 - Normalized flux decline as a function of time with various doses of Al at pH 7.0. (a) 10 ppm HA; (b) 1:1 1 ratio 5 ppm HA/ BSA mixture (i.e., 1:1 HA/BSA); (c) 10 ppm BSA. 

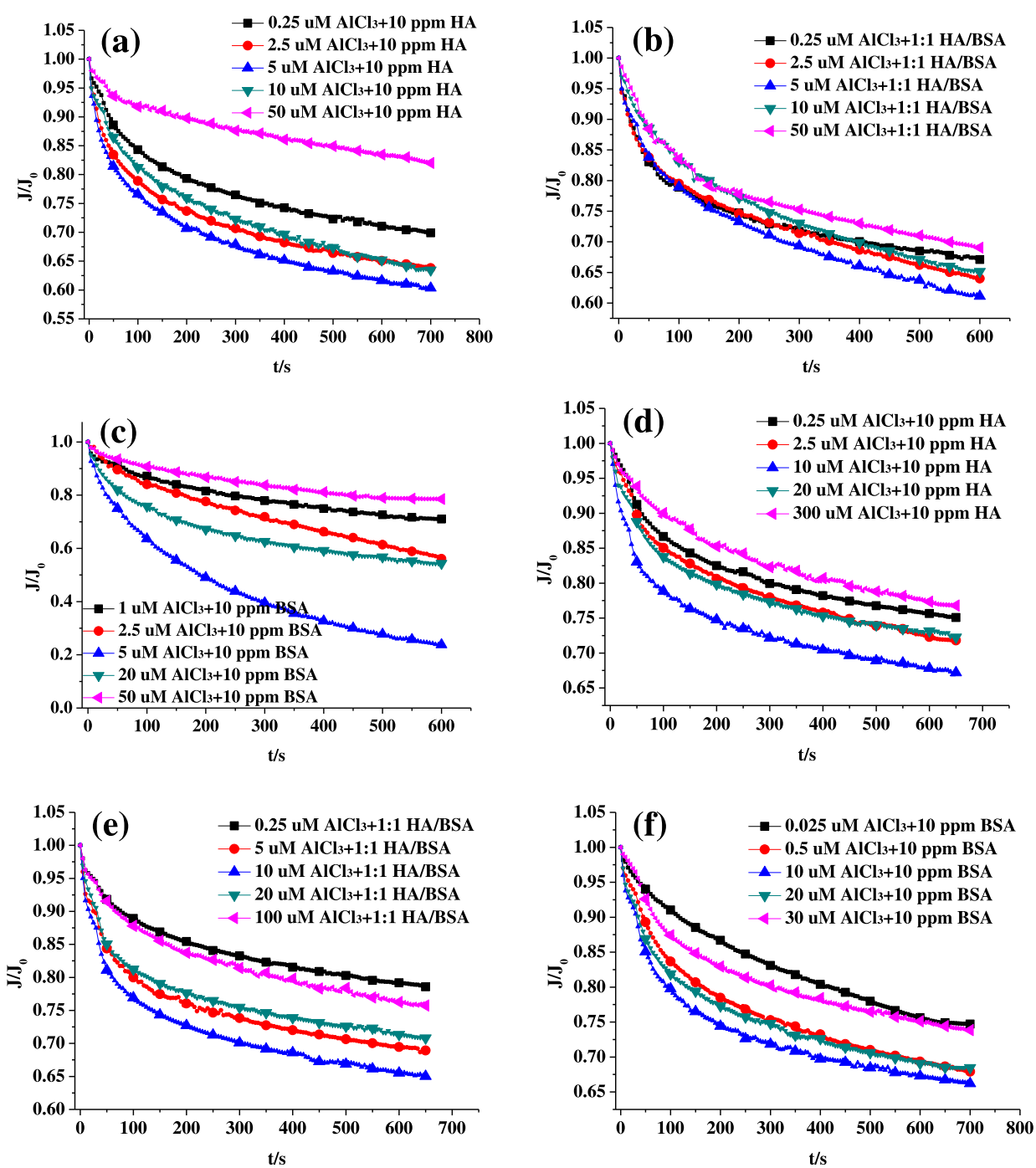

Fig. 2 - Normalized flux decline as a function of time with different doses of Al. (a) 10 ppm HA at pH 6.0; (b) 1:1 ratio 5 ppm HA/ BSA mixture (i.e., 1:1 HA/BSA) at pH 6.0; (c) 10 ppm BSA at pH 6.0; (d) 10 ppm HA at pH 8.0; (e) 1:1 ratio 5 ppm HA/BSA mixture (i.e., 1:1 HA/BSA) at pH 8.0; (f) 10 ppm BSA at pH 8.0.

to Figs. 1 and 2, the critical dose of $\mathrm{Al}$ was lower at $\mathrm{pH} 6.0$ than that at $\mathrm{pH}$ 8.0. For HA, BSA or their $1: 1_{\text {ratio }} 5 \mathrm{ppm} \mathrm{HA/BSA}$ mixture, $5 \mu \mathrm{M}$ Al could induce membrane flux reduce drastically at pH 6.0 while $10 \mu \mathrm{M} \mathrm{Al}$ was needed at pH 8.0. However, no dramatic flux decline at $\mathrm{pH} 8.0$ was found because $\mathrm{Al}$ hydrolysis species was not sufficient (Wang et al., 2008). For the $1: 1_{\text {ratio }} 5 \mathrm{ppm} \mathrm{HA} / \mathrm{BSA}$ mixture, its minimal $\mathrm{J} / \mathrm{J}_{0}$ value was similar to that caused by $\mathrm{HA}$ as a function of $\mathrm{pH}$ because protein (BSA) could be encapsulated by HA, and that was stable at pH 5.0 to 8.0 (Jeanne et al., 2011).

\subsection{Change of molecular weight distribution}

The MW distribution of HA and BSA was also investigated to know whether it would be changed or not before and after the filtration (Fig. 4). Three main doses of $\mathrm{Al}$ were chosen, which represented the minimum, the critical and the maximum dose of Al used. As seen from Fig. 4, the MW distribution of HA was from 41,477 Da to $2181 \mathrm{Da}$ before filtration, while the MW

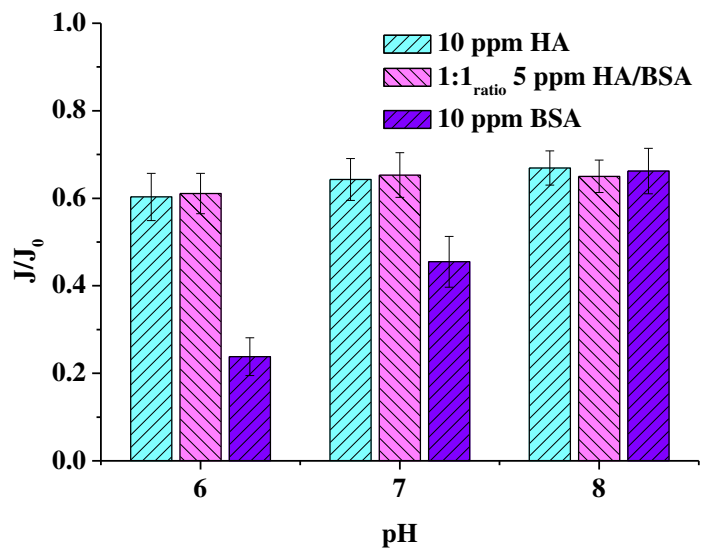

Fig. 3 - Minimal $J / J_{0}$ value caused by the critical dose of $\mathrm{Al}$ after coagulating with HA/BSA as a function of $\mathrm{pH}$. 

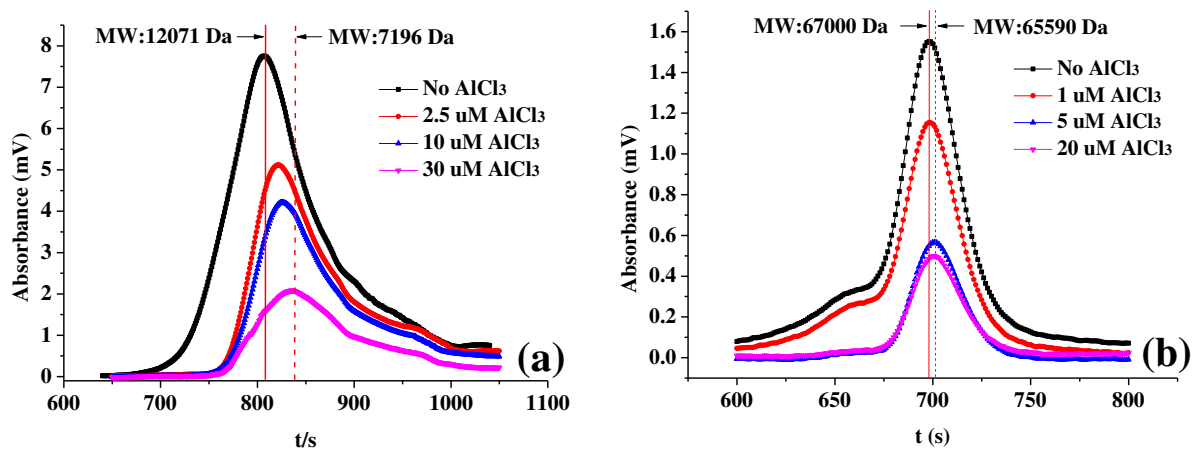

Fig. 4 - Molecular weight distribution of HA or BSA coagulated with Al before and after the filtration at pH 7.0. (a) 10 ppm HA; (b) 10 ppm BSA.

distribution of HA was from 22,134 $\mathrm{Da}$ to $1802 \mathrm{Da}$, from 20,899 Da to $1683 \mathrm{Da}$, and from 19,965 Da to $1498 \mathrm{Da}$ when the dose of $\mathrm{Al}$ was $2.5 \mu \mathrm{M}, 10 \mu \mathrm{M}$ and $30 \mu \mathrm{M}$ in the feed, respectively. It clearly showed that HA with large MW were rejected, and the peak value of the MW distribution of HA were shifted to a smaller one with increasing the dose of Al. For BSA, however, its peak value of the MW distribution was varied little after coagulation, which might be due to the single chemical characteristic of BSA. In general, the variation of the peak value (from $12,071 \mathrm{Da}$ to $7196 \mathrm{Da}$ ) of the MW distribution of HA was much more significant than that of BSA (from $67,000 \mathrm{Da}$ to $65,590 \mathrm{Da}$ ) after filtration because there were some large MW of HA which were easily rejected when coagulated with various doses of $\mathrm{Al}$.

\section{Discussion}

To know the effect of various particle sizes caused by the low doses of coagulant on the UF membrane filtration behavior, different doses of $\mathrm{Al}$ were added to the feed water with HA, BSA or $1: 1_{\text {ratio }} 5$ ppm HA/BSA mixture. Wang and Tarabara (2008) reported that pore blocking was an important fouling mechanism for porous MF and UF membranes. The fact was that the size of particles which were close to the diameter of membrane pores could cause serious membrane fouling, while smaller than the pore size or larger than the pore size cannot because particles could either filtrate or form a relatively loose layer on the membrane surface. Fig. 5 showed the particle size distribution of HA/ BSA coagulated with different low doses of Al. For HA, there were two peak values $(3.77 \mathrm{~nm}$, volume: $6.01 \%$; $82.09 \mathrm{~nm}$, volume: $53.54 \%$ ) of the particle size distribution due to a portion of non-dissolved particles. The particle size increased with increasing the dose of $\mathrm{Al}$ in the feed solution. One peak value of the particle size was $28.24 \mathrm{~nm}$ (volume: $17.40 \%$ ) when the dose of $\mathrm{Al}$ was $2.5 \mu \mathrm{M}$, while the peak values of the particle size were $39.41 \mathrm{~nm}$ (volume: 12.70\%) and $55.37 \mathrm{~nm}$ (volume: 10.60\%) when the doses of $\mathrm{Al}$ were $10 \mu \mathrm{M}$ (critical dose) and $30 \mu \mathrm{M}$, respectively. As analyzed by IB-FT, GmbH, the average diameter of the UF membrane pores used in the experiment was about $41.51 \mathrm{~nm}$. Therefore, serious flux decline was induced by the particle size of HA coagulated with $10 \mu \mathrm{M} \mathrm{Al}$ because of higher chances of blocking the membrane pores. Owning to the wide MW distribution of HA, its particle size was difficultly equal to the diameter of the membrane pore after coagulation. Although a number of particles would block some membrane pores after coagulation, the amount was fractional and that cannot cause dramatic flux reduction. Thus, the main fouling mechanism would be induced by cake layer as there were numbers of particles larger than $100 \mathrm{~nm}$. For BSA, the peak value of the particle size distribution was $7.7 \mathrm{~nm}$. The particle size also increased with increasing the dose of $\mathrm{Al}$ in the feed solution. The peak value of the particle size distribution after coagulation was $28.21 \mathrm{~nm}$ when the dose of $\mathrm{Al}$ was $1 \mu \mathrm{M}$, while the peak values of the particle size distribution were $37.84 \mathrm{~nm}$ and $105.70 \mathrm{~nm}$ when the doses of Al were $5 \mu \mathrm{M}$ (critical dose) and $20 \mu \mathrm{M}$, respectively. Thus, the particle size of BSA which was coagulated with the $5 \mu \mathrm{M}$ Al could cause drastic flux decline by blocking the membrane pores during the filtration. In comparison with the flux decline caused by HA after coagulation, BSA coagulated with Al could cause a much more serious membrane fouling due to the similarity of the particle size distribution to the membrane pore size distribution.

When there was a low dosage of $\mathrm{Al}$ in feed solution, especially when the dose was lower than the critical dose, most flocs were nano-scale, leading to a less serious flux decline because a large number of flocs could pass through the membrane pores. However, some micro-flocs were formed at the critical dose and would grow gradually with increasing the dose of Al. Therefore, more and more flocs could fully block the membrane pores and that could cause significant flux reduction, especially for the narrower MW distribution of BSA. When the dose of Al was higher than the critical dose, cake layer was formed. For the $1: 1_{\text {ratio }} 5$ ppm HA/BSA mixture, the flux decline was dominated by HA because BSA was encapsulated by HA, which induced a rare chance of the pore blocking. The MW distribution of HA were relatively wide and it was difficult to cause serious flux decline because the chances of fully blocking the membrane pores were rare (Fig. 6).

\section{Conclusions}

Up to now, more studies have focused on finding an optimal dose of coagulant in order to drastically mitigate the 

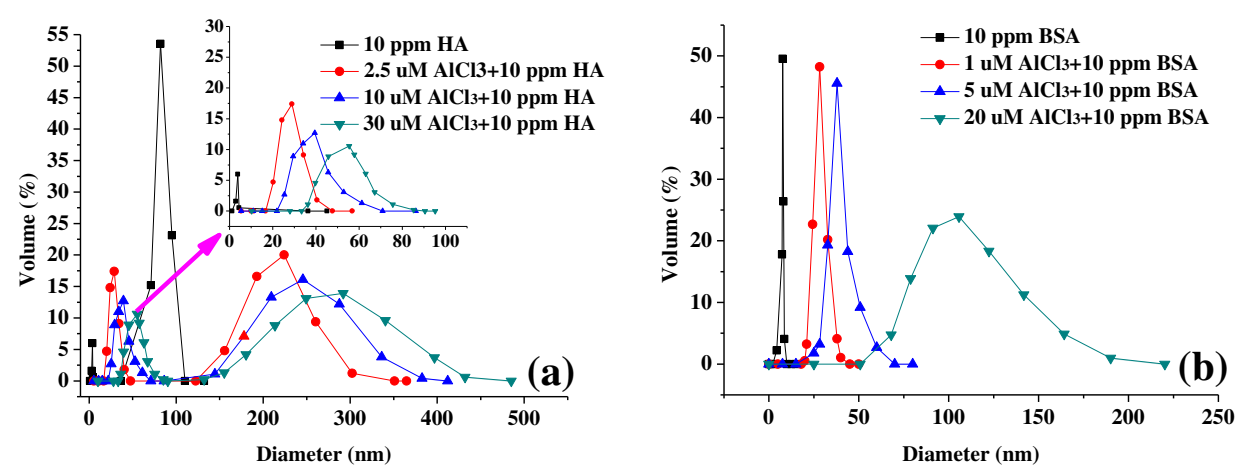

Fig. 5 - Particle size distribution of HA/BSA coagulated with Al at pH 7.0. (a) 10 ppm HA; (b) 10 ppm BSA.

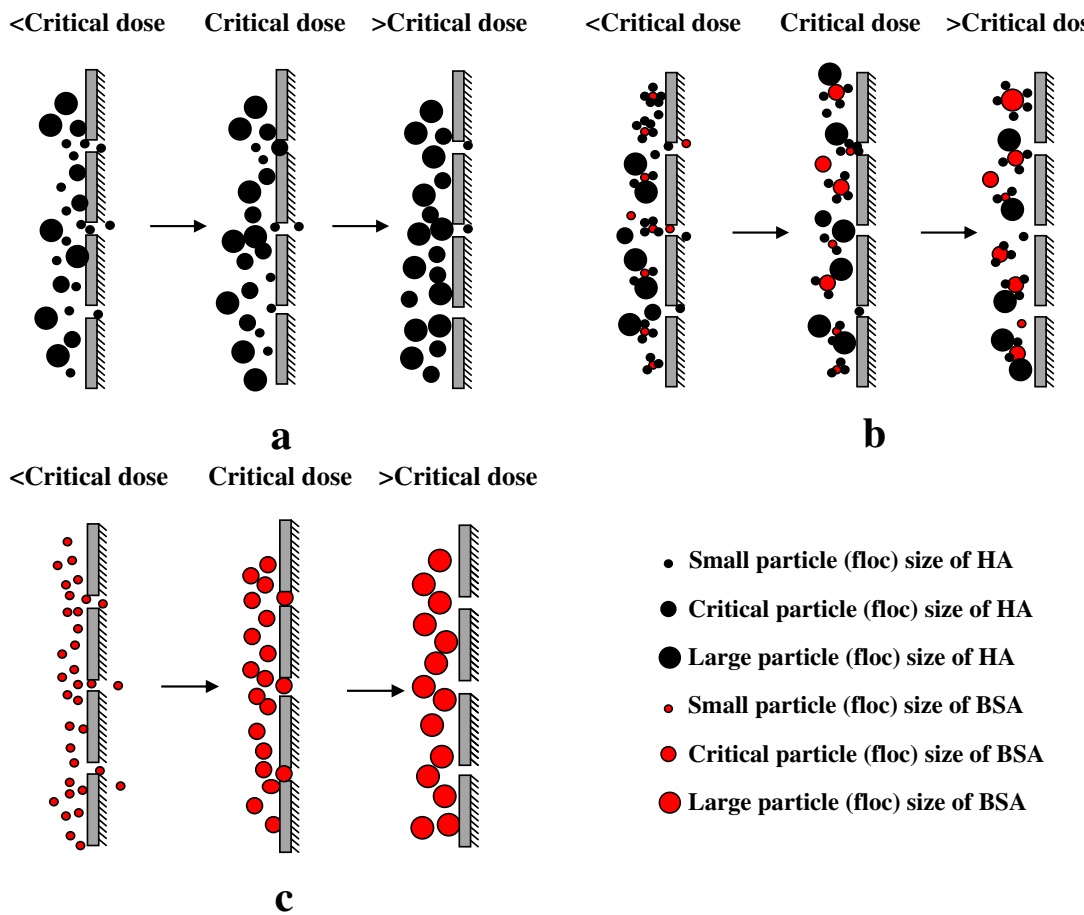

Fig. 6 - Schematic diagram of the membrane fouling mechanism. (a) HA; (b) 1:1 (mass ratio) HA/BSA; (c) BSA.

membrane fouling in the downstream treatment of membrane filtration. However, the most serious membrane fouling was investigated when there was HA or BSA in the feed water with low doses of coagulant. There was indeed a critical dose of $\mathrm{Al}$ that could exacerbate membrane fouling after coagulation, especially for BSA. The fouling mechanism was mainly induced by the particle size of HA or BSA coagulated with Al. For $\mathrm{HA}$ or $\mathrm{BSA}$, the critical dose of $\mathrm{Al}$ was relatively lower at $\mathrm{pH}$ 6.0 than that at $\mathrm{pH}$ 8.0. HA/BSA coagulated with the critical dose of Al behaved conformably except the flux. The flux decline caused by HA after coagulation was slightly affected by $\mathrm{pH}$ while that caused by BSA after coagulation was varied significantly as a function of $\mathrm{pH}$. In addition, the flux decline caused by the $1: 1_{\text {ratio }} 5 \mathrm{ppm} \mathrm{HA/BSA}$ mixture after coagulation was inclined to that caused by HA after coagulation because BSA could be encapsulated by HA in feed solution. The peak value of the MW distribution of HA coagulated with $\mathrm{Al}$ was changed much more drastically compared to that of BSA after filtration.

\section{Acknowledgments}

This research was funded by National Science and Technology Research Key Project of China (Grant No. 51138008).

R E F E R E N C E S

Aguiar, A., Lefebvre, E., Rahni, M., Legube, B., 1996. Relationship between raw water TOC and the optimal coagulants does (iron III choride). Environ. Technol. 17, 381-389. 
Al-Malack, M.H., Anderson, G.K., 1996. Coagulation-cross-flow microfiltration of domestic wastewater. J. Membr. Sci. 121 (1), 59-70.

Aoustin, E., Schäfer, A.I., Fane, A.G., Waite, T.D., 2001. Ultrafiltration of natural organic matter. Sep. Purif. Technol. 22/23 (1-3), 63-78.

Hsu, P.H., Hatcher, P.G., 2005. New evidence for covalent coupling of peptides to humic acids based on 2D NMR spectroscopy: a means for preservation. Geochim. Cosmochim. Acta 69, 4521-4533.

Hsu, P.H., Hatcher, P.G., 2006. Covalent coupling of peptides to humic acids: structural effects investigated using 2D NMR spectroscopy. Org. Geochem. 37, 1694-1704.

Huang, H., Spinette, R., O’Melia, C.R., 2008. Direct-flow microfiltration of aquasols: I. Impacts of particle stabilities and size. J. Membr. Sci. 314 (1-2), 90-100.

Huber, S.A., Balz, A., Abert, M., Pronk, W., 2011. Charaterization of aquatic humic and non-humic matter with size-exclusion chromatography-organic carbon detection-organic nitrogen detection (L-OCD-OND). Water Res. 45, 879-885.

Jeanne, E.T., René, P.S., Michael, S., 2011. Protein encapsulation by humic substances. Environ. Sci. Technol. 45, 6003-6010.

Jermann, D., Pronk, W., Meylan, S., Boller, M., 2007. Interplay of different NOM fouling mechanisms during ultrafiltration for drinking water production. Water Res. 41, 1713-1722.

Jucker, C., Clark, M.M., 1994. Adsorption of aquatic substances on hydrophobic ultrafiltration membranes. J. Membr. Sci. 97, 37-52.

Katsoufidou, K.S., Sioutopoulos, D.C., Yiantsios, S.G., Karabelas, A.J., 2010. UF membrane fouling by mixtures of humic acids and sodium alginate: fouling mechanisms and reversibility. Desalination 264, 220-227.

Katsoufidou, K., Yiantsios, S.G., Karabelas, A.J., 2007. Experimental study of ultrafiltration fouling by sodium alginate and flux recovery by backwashing. J. Membr. Sci. 300, 137-146.

Kimura, K., Hane, Y., Watanabe, Y., Amy, G., Ohkuma, N., 2004. Irreversible membrane fouling during ulrafiltration of surface water. Water Res. 38, 3431-3441.

Knicker, H., Hatcher, P.G., 1997. Survival of protein in an organicrich sediment: possible protection by encapsulation in organic matter. Naturwissenschaften 84, 231-234.

Lee, B.B., Choo, K.H., Chang, D., Choi, S.J., 2009. Optimizing the coagulant dose to control membrane fouling in combined coagulation/ultrafiltration systems for textile wastewater reclamation. Chem. Eng. J. 155, 101-107.

Listiarini, K., Sun, D.D., Leckie, J.O., 2009. Organic fouling of nanofiltration membranes: evaluating the effects of humic acid, aluminum coagulant and their combinations on the specific cake resistance. J. Membr. Sci. 332, 56-62.

Masatoshi, H., Takeshi, K., Noboru, K., Yoshikage, O., Tatsuo, M., Hideto, M., 2011. Effect of surface roughness of hollow fiber membranes with gear-shaped structure on membrane fouling by sodium alginate. J. Membr. Sci. 366, 389-397.

Maximous, N., Nakhla, G., Wan, W., 2009. Comparative assessment of hydrophobic and hydrophilic membrane fouling in wastewater applications. J. Membr. Sci. 339, 93-99.

Mo, H., Tay, K.G., Ng, H.Y., 2008. Fouling of reverse osmosis membrane by protein (BSA): effects of $\mathrm{pH}$, calcium, magnesium, ionic strength and temperature. J. Membr. Sci. 315, 28-35.

O'Melia, C.R., 1998. Coagulation and sedimentation in lakes, reservoirs and water treatment plants. Water Sci. Technol. 37 (2), 129-135.

Palacio, L., Ho, C.C., Pradanos, P., Hernandez, A., Zydney, A.L., 2003. Fouling with proteins mixtures in microfiltration: BSAlysozyme and BSA-persin. J. Membr. Sci. 222, 41-51.
Porcelli, N., Judd, S., 2010. Chemical cleaning of potable water membranes: the cost benefit of optimization. Water Res. 44, 1389-1398.

Sean, T.K., SenyoOpong, W., Zydney, A.L., 1993. The influence of protein aggregates on the fouling of microfiltration membrane during stirred cell filtration. J. Membr. Sci. 80, 175-187.

She, Q.H., Tang, C.Y., Wang, Y.N., Zhang, Z.J., 2009. The role of hydrodynamic conditions and solution chemistry on protein fouling during ultrafiltration. Desalination 249, 1079-1087.

Shon, H.K., Vigneswaran, S., Kim, In.S., Cho, J., Ngo, H.H., 2004. The effect of pre-treatment to ultrafiltration of biologically treated sewage effluent: a detailed effluent organic matter (EfOM) characterization. Water Res. 38, 1933-1939.

Shon, H.K., Vigneswaran, S., Ngo, H.H., Aim, R.B., 2005. Is semiflocculation effective as pretreatment to ultrafiltration in wastewater treatment. Water Res. 39, 147-153.

Stumm, W., Morgan, J.J., 1996. Aquatic Chemistry: Chemical Equilibria and Rates in Natural Waters, $3^{\text {rd }}$ ed. John Wiley \& Sons, Inc, New York. p. 1022.

Tan, W.F., Koopal, L.K., Norde, W., 2009. Interaction between humic acid and lysozyme, studied by dynamic light scattering and isothermal titration calorimetry. Environ. Sci. Technol. 43, 591-596.

Tan, W.F., Koopal, L.K., Weng, L.P., Van Riemsdijk, W.H., Norde, W., 2008. Humic acid protein complexation. Geochim. Cosmochim. Acta 72, 2090-2099.

Tang, C.Y., Leckie, J.O., 2007. Membrane independent limiting flux for RO and NF membranes fouled by humic acid. Environ. Sci. Technol. 41, 4767-4773.

Tran, T., Gray, S., Naughton, R., Bolto, B., 2006. Polysilicato-iron for improved NOM removal and membrane performance. J. Membr. Sci. 280 (2), 560-571.

Wang, F., Tarabara, V.V., 2008. Pore blocking mechanisms during early stages of membrane fouling by colloids. J. Colloid Interf. Sci. 328, 464-469.

Wang, J., Guan, J., Santiwong, S.R., Waite, T.D., 2008. Characterization of floc size and structure under different monomer and polymer coagulants on microfiltration membrane fouling. J. Membr. Sci. 321, 132-138.

Wang, Y.N., Tang, C.Y., 2011. Protein fouling of nanofiltration, reverse osmosis, and ultrafiltration membranes - the role of hydrodynamic conditions, solution chemistry, and membrane properties. J. Membr. Sci. 376, 275-282.

Wang, Y., Zhou, W.Z., Gao, B.Y., Xu, X.M., Xu, G.Y., 2009. The effect of total hardness on the coagulation performance of aluminum salts with different Al species. Sep. Purif. Technol. 66, 457-462.

Ye, Y., Clech, P.L., Chen, V., Fane, A.G., 2005a. Evolution of fouling during crossflow filtration of model EPS solutions. J. Membr. Sci. 264, 190-199.

Ye, Y., Clech, P.L., Chen, V., Fane, A.G., Jefferson, B., 2005 b. Fouling mechanisms of alginate solutions as model extracellular polymeric substances. Desalination 175, 7-20.

Ye, Y., Chen, V., Fane, A.G., 2006. Modeling long-term subcritical filtration of model EPS solutions. Desalination 191, 318-327.

Yuan, W., Zydney, A.L., 1999. Humic acid fouling during microfiltration. J. Membr. Sci. 157, 1-12.

Zang, X., Van Heemst, J.D.H., Dria, K.J., Hatcher, P.G., 2000. Encapsulation of protein in humic acid from a histosol as an explanation for the occurrence of organic nitrogen in soil and sediment. Org. Geochem. 31, 679-695.

Zazouli, M.A., Nasseri, S., Ulbricht, M., 2010. Fouling effects of humic and alginic acids in nanofiltraion and influence of solution composition. Desalination 250, 688-692. 